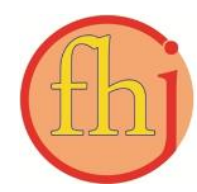

Faletehan Health Journal, 8 (3) (2021) 182-186

www. journal.Ippm-stikesfa.ac.id/ojs/index.php/FHJ

ISSN 2088-673X | e-ISSN 2597-8667

\title{
Analisis Pendampingan Lansia yang Mengalami Penyakit Rheumatoid Arthritis pada Lembaga Kesejahteraan Sosial di Aceh
}

\author{
Iskandar $^{1^{*},}$ Riyan Mulfianda ${ }^{1}$ \\ ${ }^{1}$ Program Studi Ilmu Keperawatan Fakultas Kedokteran Universitas Abulyatama \\ *Correspondence Author: iskandar_psik@abulyatama.ac.id
}

\begin{abstract}
Abstrak
Pendampingan lansia di Lembaga Kesejahteraan Sosial saat ini umumnya dilakukan oleh pekerja sosial bukan bidang kesehatan. Hal ini berpotensi terjadi kelemahan dalam perawatan lansia yang mengakibatkan menurunnya kondisi kesehatan lansia terutama yang mengalami penyakit kronik rematik. Penelitian ini bertujuan melakukan analisis pendampingan lansia yang mengalami penyakit rheumatodi arthritis pada lansia yang tinggal di panti jompo Darussa'adah Lhokseumawe provinsi Aceh. Desain penelitian ini menggunakan kuantitatif deskriptif dengan analisis descriptive statistics. Populasi dalam penelitian ini adalah seluruh lansia yang mengalami rematik dan jumlah sampel berjumlah 36 responden dengan teknik purposive sampling. Hasil analisis univariat menunjukkan pendampingan yang dilakukan oleh pendamping lansia paling banyak berkategori kurang, yaitu sebanyak 19 responden (52.8\%), monitoring negatif sebanyak 19 responden (52.8\%), edukasi negatif sebanyak 21 responden (58.3\%) dan motivasi kurang sebanyak 18 responden (50\%). Hasil analisis bivariat menunjukkan ada hubungan pendampingan lansia dengan ketergantungan perawatan lansia yang mengalami masalah kesehatan kronis rematik ( $p$ value, 0.001). Pengelola Lembaga Kesejahteraan Sosial sebaiknya dapat berkoordinasi dengan Dinas Kesehatan setempat untuk meminta pendampingan dan perawatan lansia oleh perawat bagi lansia yang mengalami penyakit kronis rematik.

Kata Kunci: Pendampingan Lansia, Rheumatoid Arthritis, Institusi Kesejahteraan Sosial
\end{abstract}

\section{Analysis on the Assistance of Elderly with Rheumatoid Arthritis in a Social Welfare Institution in Aceh}

\begin{abstract}
Nowadays, elderly assistance in Social Welfare Institutions is generally carried out by non-medical social workers. This potentially causes a shortcoming in elderly care, resulting on the decreased condition of the elders' health especially those with a chronic rheumatic diseases. This reasearch aimed to analyze the assistance of elderly with Rheumatoid Arthritis (RA) at Nursing Home Darussa'adah, Lhokseumawe, Aceh Province. The research design was descriptive quantitative with descriptive statistics analysis. The population were all elderly people with rheumatism and the samples were 36 respondents who were selected by using purposive sampling technique. The results of univariate analysis showed that the elderly assistance was mostly categorized poor, namely as many as 19 respondents (52.8\%), negative monitoring was obtained by 19 respondents (52.8\%), negative education was received by 21 respondents (58.3\%), and lack of motivation was gotten by 18 respondents (50\%). The results of bivariate analysis showed that there was a relationship between elderly assistance and elderly dependence in elders with chronic RA (p value 0.001). The managers of Social Welfare Institution should coordinate with the local Health Office to request elderly assistance and care by nurses for the elders with chronic rheumatic diseases.
\end{abstract}

Keywords: Elderly Assistance, Rheumatoid Arthritis, Social Welfare Institution 
Faletehan Health Journal, 8 (3) (2021) 182-186

www. journal.Ippm-stikesfa.ac.id/ojs/index.php/FHJ

ISSN 2088-673X | 2597-8667

\section{Pendahuluan}

Penuaan merupakan suatu proses alami yang tidak dapat dihindarkan, berjalan terus menerus dan berkesinambungan (Kemenkes RI, 2001). Semua orang akan mengalami proses menjadi tua, dan masa itu merupakan masa hidup yang terakhir dimana pada masa ini seseorang akan mengalami kemunduran fisik, mental, dan sosial sedikit demi sedikit sampai tidak dapat melakukan tugasnya sehari-hari (Lumongga, 2013), (Kementerian Kesehatan Indonesia, 2016).

World Health Organization (WHO) tahun 2020 jumlah lansia mencapai 28,800,000 $(11,34 \%)$ dari total populasi. Proporsi jumlah lansia di Indonesia pada di tahun 2020 mengalami peningkatan $11.34 \%$. Data Badan Pusat Statistik Aceh (2021) jumlah lansia tahun 2020 di provinsi Aceh mencapai 16,69\%. Sedangkan data Dinas Sosial Aceh (2021) jumlah lansia yang tinggal di LKS (Lembaga Kesejahteraan Sosial) berjumlah 467 orang. Seiring bertambahnya jumlah lansia di Aceh jumlah LKS ikut bertambah, menurut laporan Dinas Sosial Aceh, 2021 di Propinsi Aceh terdapat 14 LKS terdiri dari 13 LKS yang dikelola oleh masyarakat dan 1 LKS dibawah pemerintah Aceh. Dengan bertambahnya jumlah penduduk dan usia harapan hidup lansia akan menimbulkan berbagai aspek masalah antara lain aspek medis karena dari banyaknya masalah yang dihadapi lansia, masalah kesehatanlah yang jadi masalah prioritas dalam kehidupan lansia seperti munculnya penyakitpenyakit yang sering terjadi pada lansia (Nugroho, 2013), (Aspiani, 2014), (Kementerian Kesehatan Indonesia, 2013).

Berdasarkan data Riskesdas Kementerian Kesehatan Indonesia (2018) didapatkan prevalensi penyakit sendi di Aceh adalah 13,3\% tertinggi se Indonesia, lansia berusia > 65 tahun prevalensi mencapai $18.6 \%$ dan $9.90 \%$ umumnya diderita oleh petani/buruh tani. Rematik termasuk kedalam 10 (sepuluh) penyakit terbanyak di Aceh dimana tahun 2020 dilaporkan kasus Rematik yang dirawat ditatanan Puskesmas berjumlah 103.073 (Anurogo, D \& Wulandari, 2012), (Dinas Kesehatan Aceh, 2021).

Kebanyakan penyakit rematik berlangsung kronis, yaitu sembuh dan kambuh kembali secara berulang-ulang sehingga menyebabkan kerusakan sendi secara menetap. Jika tidak diperhatikan penyakit tersebut akan berakibat buruk bagi lansia, muncul komplikasi pada nodul subkutan, miositis, kelainan pada katup jantung, tromboemboli serta splenomegali (Suratun, dkk, 2008), (Suiraoka, 2012). Namun demikian, keluhan mudah capek, lemah, lesu, demam, takikardia, berat badan menurun, dan anemia juga dirasakan oleh lansia, yang mengakibatkan hambatan mobilitas terutama dalam hal berjalan, mengurus diri sendiri, berpakaian, dan lainnya dalam activity daily living. (Iskandar et al., 2020).

Pemenuhan kebutuhan sehari-hari lansia memerlukan pendampingan baik di rumah maupun di panti sosial. Saifullah dan Hastuti (2013) menjelaskan bentuk-bentuk pendampingan perawatan diri lansia di Panti Wreda dirumuskan sebagai berikut ; pendampingan lansia, monitor lansia, edukasi lansia, motivasi lansia dan bantuan lainnya. (Friedman (2010) pendamping lansia (caregiver) merupakan individu yang memberikan perhatian kepada individu lainnya yang memiliki masalah tertentu, bisa berasal dari anggota keluarga ataupun tenaga profesional, dan bisa tinggal bersama atau tidak (Kadar, et al., 2012), (Direktorat Pelayanan Sosial Lanjut Usia, 2016). Idealnya pendamping yang dibutuhkan lansia dalam perawatan rematiknya adalah perawat dimana profesi ini sudah teruji secara keilmuan keprofesian dalam merawat pasien dengan berbagai kondisi. (Iskandar et al., 2020).

Namun kenyataan di LKS panti jompo Darussa'adah Lhokseumawe pendampingan lansia saat ini justru dilakukan oleh swadaya keluarga pengelola LKS berjumlah 12 orang dan semuanya bukan berlatar belakang kesehatan sehingga perlu diamati secara menyeluruh tingkat optimalisasi perawatan yang dilakukannya dengan kasus tersebut. Tujuan penelitian ini untuk menganalisis pendampingan lansia yang dilakukan oleh LKS. Oleh karena itu kondisi ini perlu segera diamati demi keberlangsungan peningkatan derajat kesehatan lansia dengan masalah penyakit kronis rematik.

\section{Metodologi Penelitian}

Desain penelitian yang digunakan dalam penelitian ini melalui pendekatan Cross Sectional dengan berfokus pada analisis pendampingan lansia di LKS. Populasi penelitian yakni seluruh lansia yang tinggal di LKS khususnya lansia Panti Jompo Darussa'adah Lhokseumawe Provinsi Aceh. Sampel penelitian yakni lansia yang mengalami penyakit kronis rematik berjumlah 36 
orang. Teknik sampling yang digunakan pada penelitian ini adalah nonprobability sampling jenis purposive sampling. Kriteria inklusi penelitian ini adalah lansia yang menderita rematik dan bersedia menjadi responden. Sedangkan kriteria eklusi nya adalah lansia yang tidak kooperatif dan tidak berada di lokasi saat penelitian berlangsung. Penelitian dilaksanakan pada bulan Juni 2021. Instrumen pengumpulan data menggunakan kuesioner yang terdiri dari data demografi, skrining rematik, monitor lansia, edukasi lansia, motivasi lansia dan pendampingan lansia. Analisis data univariat menggunakan descriptive statistics sedangkan data Bivariat menggunakan analisis uji Chi Square.

Hasil dan Pembahasan

Tabel 1. Data Demografi Responden ( $\mathrm{n}=36)$

\begin{tabular}{lcccc}
\hline Karakteristik & n & \% & Mean & StDv \\
\hline Umur & & & & \\
$\quad$ Usia Pertengahan & 1 & 2.8 & & \\
Lanjut Usia & 27 & 75 & 70.97 & 6.461 \\
$\quad$ Lanjut Usia Tua & 8 & 22.2 & & \\
\hline Lama Tinggal & & & & \\
$\quad$ 1 Tahun & 16 & 44.4 & - & - \\
$\quad$ 1 Tahun & 20 & 55.6 & - & - \\
\hline Riwayat Penyakit & & & & \\
$\quad$ < Tahun & 32 & 88.9 & - & - \\
$>$ 1 Tahun & 4 & 11 & - & - \\
\hline Gejala & & & & \\
$\quad$ < Gejala & 17 & 47.2 & - & - \\
$\quad$ 3 Gejala & 19 & 52.8 & - & - \\
\hline Monitor & & & & \\
Positif & 17 & 47.2 & - & - \\
$\quad$ Negatif & 19 & 52.8 & - & - \\
\hline Edukasi & & & & \\
Positif & 15 & 41.7 & - & - \\
Negatif & 21 & 58.3 & - & - \\
\hline Motivasi & & & & \\
Baik & 18 & 50 & - & - \\
Kurang & 18 & 50 & - & - \\
\hline$\quad$ Total & $\mathbf{3 6}$ & $\mathbf{1 0 0}$ & & \\
\hline
\end{tabular}

Tabel 1 menunjukkan distribusi responden berdasarkan umur pada 36 responden, hasil dari data tersebut didapatkan nilai mean sebesar 70.97, dengan standar deviasi sebesar 6.461, yang paling banyak pada umur lanjut usia sebanyak 27 orang (75\%), yang menandakan bahwa mayoritas responden berusia 60-74 tahun. Data distribusi responden mayoritas lama tinggal $>1$ tahun $(n=20$, $55.6 \%$ ). Data distribusi riwayat responden menderita penyakit rematik mayoritas $<1$ tahun $(\mathrm{n}=32,88.9 \%)$. Data distribusi gejala yang dirasakan responden menderita penyakit rematik mayoritas $>3$ gejala $(n=19,52.8 \%)$. Data distribusi monitor yang dilakukan pendamping terhadap responden mayoritas negatif $(\mathrm{n}=19,52.8 \%)$. Data distribusi edukasi yang dilakukan pendamping terhadap responden mayoritas negatif $(n=21$, $58.3 \%$ ). Dan data distribusi motivasi yang diberikan pendamping terhadap responden didapatkan hasil yang berimbang antara baik dan kurang $(\mathrm{n}=18,50 \%)$.

Tabel 2. Pendampingan dan Ketergantungan Lansia Dengan Penyakit Rematik $(\mathrm{n}=36)$

\begin{tabular}{lcc}
\hline \multicolumn{1}{c}{ Variabel } & N & $\mathbf{\%}$ \\
\hline Pendampingan lansia & & \\
Baik & 17 & 47.2 \\
Kurang & 19 & 52.8 \\
\hline Ketergantungan rematik & & \\
Self Care & 9 & 11.1 \\
Partial Care & 16 & 13.9 \\
\hline \multicolumn{1}{c}{ Total } & $\mathbf{3 6}$ & $\mathbf{1 0 0}$ \\
\hline
\end{tabular}

Berdasarkan data tabel 2 menunjukkan pendampingan yang dilakukan oleh pendamping LKS yang mayoritas kategori kurang $(n=19$, $52.8 \%$ ). sedangkan berdasarkan data distribusi tingkat ketergantungan lansia dengan masalah kesehatan rematik paling dominan adalah partial care $(\mathrm{n}=16,13,9 \%)$.

Tabel 3. Hasil Uji Korelasi Cross Sectional $(\mathrm{n}=36)$

\begin{tabular}{|c|c|c|c|c|}
\hline \multirow{2}{*}{ Rematik } & \multicolumn{2}{|c|}{ Pendampingan } & \multirow{2}{*}{$\begin{array}{c}P- \\
\text { Value }\end{array}$} & \multirow{2}{*}{$\alpha$} \\
\hline & Kurang & Baik & & \\
\hline Partial Care & 19 & 1 & \multirow{2}{*}{0.001} & \multirow{2}{*}{0.05} \\
\hline Self Care & 0 & 16 & & \\
\hline Total & 19 & 17 & & \\
\hline
\end{tabular}

Data tabel 3 memperlihatkan bahwa nilai signifikansi (p value) sebesar 0.001 dimana nilai tersebut lebih kecil dari nilai $\alpha(0.05)$ sehingga dapat disimpulkan bahwa ada hubungan pendampingan lansia dengan ketergantungan perawatan lansia dengan masalah kesehatan kronis rematik.

Konsep pendampingan dalam penelitian ini memuat 4 (empat) hal, yakni : pendampingan, monitor, edukasi dan motivasi yang dilakukan oleh 
Faletehan Health Journal, 8 (3) (2021) 182-186

www. journal.Ippm-stikesfa.ac.id/ojs/index.php/FHJ

ISSN 2088-673X | 2597-8667

pendamping pada lansia yang mengalami penyakit kronik rematik di LKS. Hasil penelitian diketahui bahwa pendampingan yang dilakukan oleh pendamping LKS yang paling banyak kategori kurang sebanyak 19 orang (52.8\%). Pendampingan yang dilakukan pada lansia dilakukan dengan mendampingi klien dalam melaksanakan perawatan diri lansia terutama lansia dengan kondisi mengalami rematik. Pendampingan yang dimaksud adalah melakukan supervisi pada saat lansia melakukan aktifitas sehari. Pendampingan yang masih kurang dilakukan oleh pendamping lansia diantaranya kurang menemani berjalan, menuntun lansia saat berjalan, berpindah dari satu tempat ke tempat lainnya, memproteksi sendi lansia agar tidak beraktifitas berat, menemani lansia saat membutuhkan pelayanan fisioterapi, dan mendampingi lansia saat dirujuk ke RS. Harusnya semua kebutuhan pendampingan ini disesuaikan dengan kebutuhan serta keluhan tingkat kronik rematik pada lansia, dan perlu dilakukan penanganan segera jika kondisi mengarah pada terganggunya kemandirian lansia ditambah dengan mayoritas lansia tingkat ketergantungnya adalah partial care. (Bulechek, et al., 2008).

Penelitian ini juga ditemukan bahwa monitoring rematik yang dilakukan oleh pendamping lansia di LKS paling banyak kategori negatif sebanyak 19 orang (52.8\%). Monitor dilakukan dengan memonitor kemampuan selfcare lansia dengan rematik, harusnya pendamping dapat melakukan dengan pengkajian melalui wawancara, maupun observasi meliputi kemampuan lansia melakukan aktivitas sehari-hari, berpindah, menyiapkan makan dan makan, juga termasuk komunikasi; memonitor kebutuhan perawatan lansia terkait dengan rematik, hal ini dilakukan oleh LKS termasuk dalam monitoring adalah melakukan cek ulang riwayat lansia secara rutin terkait dengan penyakit yang pernah diderita, juga disertai dengan pemeriksaan fisik dan penunjang yang diperlukan secara berkala. Bentuk kegiatan dalam monitor lansia tersebut masih belum tepat dilakukan oleh pendamping karena idealnya jika kondisi lansia dengan ketergantungan partial care atau intermediate care maka dilakukan monitor setiap 4 jam. Hal ini sesuai dengan konsep Douglas (1984, dalam (Swanburg \& Swanburg, 1999) kategori perawatan partial memerlukan waktu 3-4 jam/hari untuk dibantu kebersihan diri, makan minum, observasi tanda-tanda vital setiap 4 jam, membantu ambulasi serta termasuk mencatat pemasukan dan pengeluaran urin jika lansia terpasang kateter urin.

Penelitian ini juga menemukan bahwa edukasi lansia dengan penyakit rematik yang dilakukan oleh pendamping lanisa di LKS paling banyak kategori negatif sebanyak 21 orang (58.3\%). Edukasi yang dimaksud dalam hasil penelitian ini adalah pemberian informasi terkait dengan lansia. Informasi atau pendidikan yang dimaksud adalah pendidikan kesehatan mengenai cara berjalan yang benar, penggunaan alat bantu jalan, serta penggunaan herbal bagi lansia. Pendidikan kesehatan yang diberikan ke lansia ini meliputi pendidikan kesehatan yang terkait dengan optimalisasi pendampingan lansia dengan penyakit rematik yang dilakukan pada lansia di LKS.

Hasil yang negatif karena ditemukan belum ideal pada pelaksanaan pendidikan kesehatan oleh pendamping yang semestinya dapat disampaikan secara individual maupun dalam kelompok jika mampu namun bisa mengundang pihak Puskesmas atau dinas kesehatan dalam edukasi kesehatan. Pendamping dapat memperhatikan bila memberikan pendidikan kesehatan dalam kelompok lansia, perlu mengidentifikasi terlebih dahulu pengetahuan spesifik yang perlu ditingkatkan, serta menyesuaikan cara penyampaian dengan kemampuan kelompok lansia yang menjadi sasaran.

Mengajarkan keluarga atau pemberi pelayanan bagi klien dalam pendampingan lansia dengan penyakit rematik. Pengajaran pada pemberi perawatan di LKS dapat berupa pendidikan kesehatan mengenai cara berjalan yang benar, menggunakan alat bantu jalan, pembatasan aktifitas berat, penggunaan penopang sendi saat beraktifitas, informasi rutin minum obat rematik dan tata cara mengurangi rasa sakit pada sendi dengan ramuan herbal di LKS (Forciea, et al., 2004).

Penelitian ini juga diperoleh hasil bahwa motivasi lansia dengan rematik yang dilakukan oleh pendamping di LKS secara umum berimbang yakni sebanyak 18 orang (50\%) kategori baik begitupun dengan kategori kurang sebanyak 18 orang $(50 \%)$. Motivasi pada lansia meliputi motivasi untuk meningkatkan kemandirian lansia dalam melakukan perawatan rematik.

Tindakan motivasi yang dilakukan pendamping lansia antara lain mendorong penggunaan kruk, tongkat, dan walker; motivasi 
lansia untuk dapat melakukan toiletting secara mandiri; mendapatkan semangat beribadah dan doa agar segera sembuh dari rematik serta memberikan semangat mengikuti kegiatan pemeriksaan kesehatan yang dilaksanakan oleh pihak berwenang.

Tindakan yang dilakukan oleh pendamping dalam memotivasi lansia melakukan perawatan rematik, tersebut sesuai dengan teori yaitu motivasi pelaksanaan pendampingan sesuai dengan kemampuan lansia. Pelaksanaan pendampingan pada lansia mungkin akan berbeda setiap harinya, sehingga selain perlu dimonitor peningkatan dan penurunan kemampuan perawatan rematik lansia, juga dengan memberikan motivasi untuk meningkatkan, maupun mempertahankan perawatan yang sudah atau masih dapat dilakukan oleh lansia (Bulechek, et al., 2008).

\section{Simpulan}

Analisis pendampingan lansia dengan masalah kesehatan rheumatoid arthritis pada lembaga kesejahteraan sosial di Aceh secara signifikan berada pada kategori kurang sebanyak 19 responden (52.8\%). Hasil bivariat pada penelitian ini didapatkan ada hubungan pendampingan lansia dengan ketergantungan perawatan lansia yang mengalami masalah kesehatan kronis rematik ( $\mathrm{p}$ value, 0.001).

\section{Referensi}

Anurogo, D \& Wulandari, A. (2012). 45 Penyakit yang Banyak Ditemukan di Masyarakat (Pertama). Andi.

Aspiani, R. Y. (2014). Buku Ajar Asuhan Keperawatan Gerontik, Aplikasi NANDA, NIC dan NOC. CV. Trans Info Media.

Azam David Saifullah, Y. D. H. (2013). PELAKSANAAN SELF-CARE ASSISSTANCE DI PANTI WREDA Azam. Jurnal Keperawatan Komunitas, 1(2), 94100.

Bulechek, G. M., Butcher, H. K., \& D., \& M., J. (2008). Nursing Interventions Classifications (NIC). Mosby.

Dinas Kesehatan Aceh. (2021). Profil Kesehatan Aceh Tahun 2020. Pemerintah Aceh. www.dinkes.acehprov.go.id

Dinas Sosial Aceh. (2021). Data Lembaga Kesejahteraan Sosial Lanjut Usia (LKSLU) di Provinsi Aceh Tahun 2020. Pemerintah Aceh.

Direktorat Pelayanan Sosial Lanjut Usia. (2016).
Petunjuk Pelaksanaan Pelayanan Pendampingan dan Perawatan Sosial Lanjut Usia. Yansos Dalam dan Luar Panti.

Forciea, M. A., Schwab, E, P., Raziano, D. B.,\& Moury, R. L. (2004). Geriatric Secrets (3rd ed.). Hanley \& Belfus.

Friedman, M. (2010). Buku Ajar Keperawatan Keluarga : Riset, Teori dan Praktek (5th ed.). EGC.

Indonesia, D. K. R. (2001). Pedoman Pembinaan Kesehatan Usia Lanjut Bagi Petugas Kesehatan. Direktorat Bina Kesehatan Keluarga.

Iskandar, Kamil, H., Mutiawati, E., \& Susanti, S. S. (2020). Caregivers' Experiences in Providing Self-Care Needs of Elderly with Rheumatoid Arthritis: A Phenomenology Study in Aceh, Indonesia. Ainc 2018, 119124. https://doi.org/10.5220/0008395301190124

Kadar, KS, Francis, K, Sellick, K. (2012). Ageing in Indonesia-health Status and Challenges for the Future. Journal of Ageing International, 14(36), 261-270.

Kementerian Kesehatan Indonesia. (2013a). Populasi Lansia Diperkirakan Terus Meningkat Hingga Tahun 2020. Pusat Komunikasi Publik. www.depkes.go.id

Kementerian Kesehatan Indonesia. (2018b). Riset Kesehatan Dasar (RISKESDAS). Balitbang Kemenkes RI.

Kementerian Kesehatan Indonesia. (2016). Infodatin Situasi Lanjut Usia (Lansia) di Indonesia. Pusat Penelitian dan Pengembangan Kesehatan.

Lumongga, L. N. (2013). Depresi Tinjauan Psikologis. Prenada Media Group.

Nugroho, W. (2013). Keperawatan Gerontik. EGC.

Statistik, B. P. (2021). Proporsi Penduduk Usia 50 Tahun Ke Atas. https://www.bps.go.id/indicator/12/1811/\%09 1/proporsi-penduduk-50-tahun-ke-atas.html

Suiraoka. (2012). Penyakit Degeneratif. Nuha Medik.

Suratun, Heryati, Manurung. S, \& R. E. (2008). Klien Gangguan Sistem Muskuloskeletal: Seri Asuhan Keperawatan. EGC.

Swanburg, R.C. \& Swanburg, R. (1999). Introductory Management and Leadership for Nurse. Jones and Barlett Publishers. 